\title{
PENGEMBANGAN PERANGKAT PEMBELAJARAN MATERI PERSEGI DAN PERSEGI PANJANG MENGGUNAKAN STRATEGI REACT
}

\author{
Maiviyani $^{1}$, Theresia Laurens ${ }^{2}$, Christi Matitaputty ${ }^{3}$ \\ ${ }^{1,2,3}$ Program Studi Pendidikan Matematika Fakultas Keguruan dan Ilmu Pendidikan,Universitas Pattimura \\ Jalan Ir. M. Putuhena, Ambon, Indonesia \\ e-mail: ${ }^{1}$ maiviyani@gmail.com; ${ }^{3}$ chmatitaputty@gmail.com
}

\begin{abstract}
Abstrak
Pendidikan pada masa sekarang sudah menjadi kebutuhan, kebutuhan akan ilmu yang didapat melalui proses belajar baik disekolah maupun belajar dari lingkungan tempat tinggal. Kemampuan matematika merupakan hal penting bagi kehidupan sehari-hari, ketika siswa bekerja dalam aktivitas yang berdasarkan pada situasi kehidupan sehari-hari, mereka melihat cara penerapan keterampilan matematika yang sedang mereka pelajari terhadap dunia nyata. Stategi pembelajaran REACT merupakan salah satu strategi pembelajaran yang menggunakan lingkungan sebagai salah satu sumber pembelajaran. Selain itu proses pembelajaran mengajar dengan cara belajar siswa aktif (CBSA) guru harus lebih aktif mempersiapkan bahan pelajaran, merencanakan proses yang akan dilaksanakan seperti RPP, mempersiapkan evalusai seperti LKS dan tindak lanjut. Dari hasil penelitian pengembangan perangkat pembelajaran aktivitas siswa mencapai 91,25\% dan tingkat keberhasilan siswa mencapai 70\%. Dengan demikian pengembangan perangkat pembelajaran materi persegi dan persegi panjang menggunakan strategi REACT memiliki efek baik bagi keaktifan siswa dan hasil belajar siswa.
\end{abstract}

Kata Kunci: Strategi REACT, CBSA, Pengembangan Perangkat Pembelajaran

\section{DEVELOPMENT OFSQUARE AND RECTANGLE LEARNING DEVICES USING RELATING, EXPERIENCING, APPLYING, COOPERATING, TRANSFERING(REACT) FOR GRADE VII STUDENTS MTsN/SMP}

\begin{abstract}
Education in the present has become a necessity, the need for knowledge gained through the learning process both in school and learning from the environment of residence. Mathematical skills are important for everyday life, when students work in activities that are based on everyday life situations; they see ways of applying the mathematical skills they are learning to the real world. Thelearning strategy REACT is one of the learning strategies that use the environment as a source of learning. Besides the teaching learning process with active student learning methods (CBSA) the teacher must be more active in preparing lesson material, planning the process to be carried out such as RPP, preparing evaluation such as LKS and follow-up. From the results of the study the development of learning tools for student activities reached $91.25 \%$ and the success rate of students reached $70 \%$. Thus the development of a square and rectangular learning device using the REACTstrategy has a good effect on student activity and student learning outcomes
\end{abstract}

Keywords: REACT Strategy, CBSA, Learning Device Development

\section{Pendahuluan}

Pendidikan pada masa sekarang sudah menjadi sebuah kebutuhan. Kebutuhan akan ilmu yang didapat melalui proses belajar, baik itu di sekolah maupun belajar dari lingkungan tampat tinggal. Menurut Morgan (Thobroni \& Mustofa, 2012 : 19) belajar dapat diartikan sebagai setiap perubahan yang relative menetap dalam tingkah laku yang terjadi sebagai suatu hasil dari pengalaman.

Menurut Joyce Bruce, dkk (2009: 7) mangatakan cara penerapan suatu pembelajaran akan berpengaruh besar terhadap kemampuan siswa dalam mendidik diri meraka sendiri. Guru 
sukses bukan sekedar penyaji yang kharismatik dan persuasif, melainkan mereka yang melibatkan para siswa dalam tugas-tugas yang sarat muatan kognitif dan sosial serta mengajari mereka bagaimana mengerjakan tugas-tugas tersebut secara produktif .

Menurut Muschla dan Gary (2009: XV) kemampuan dalam matematika merupakan hal yang penting bagi keberhasilan dalam kehidupan sehari-hari. Dewasa ini para siswa dituntut untuk memahami mengenai dasar- dasar matematika seperti kemampuan berpikir logis, mengumpulkan, menganalisis, menyusun data, membuat keputusan, dan menyelesaiakan masalah rumit dengan beberapa langkah. Tugas-tugas tersebut bermanfaat bagi siswa seperti ketika siswa bekerja dalam aktivitas yang berdasarkan pada situasi kehidupan sehari-hari, mereka melihat cara penerapan keterampilan matematika yang sedang mereka pelajari terhadap dunia nyata.

Dewasa ini kurikulum 2013 lebih menuntut siswa untuk aktif dalam proses pembelajaran, guru sebagai motivator serta fasilisator harus mampu menyusun atau merancang suatu proses pembelajaran agar pembelajaran matematika tidak lagi telihat monoton dan membosankan. Sejalan dengan hal tersebut Theresia, dkk (2014: 572) mennyatakan bahwa "In 2013 curriculum, learning mathematics emphasized linkage between mathematics content and real life activity. This cause of human activity always have in contact with the phenomena related to the mathematical concept it's means that although the objectof mathematics is abstract, but in learning process we can use a realistic approach, so it is expected that students not feel that mathematics is a difficult material."

Cockroft (Uno, 2007: 129 ) menyatakan matematika sangat dibutuhkan dan berguna dalam kehidupan sehari-hari.Berdasarkan hal tersebut perlunya proses pembelajaran dengan menggunakan lingkungan sekitar sebagai salah satu sumber belajar yang dapat dirancang oleh guru, hal tersebut membutuhkan kreatifitas siswa sendiri untuk terlibat aktif dalam proses pembelajaran, seperti pembelajaran yang dirancang dalam diskusi kelompok. Dalam diskusi kelompok sendiri memungkin terjadinya proses saling membantu sesama anggota kelompok dan berbagi dengan kelompok lain dalam proses presentasi kelompok.

Guru bukan merupakan satu-satunya sumber pengetahuan. Ahmadi \& Sofan (2014:3738) mengatakan guru hanya berfungsi sebagai fasilisator. Apa yang dikemukan oleh guru masih bersifat "hipotesis"? oleh karena itu murid perlu mengaji kebenaran apa yang dikemukan oleh guru. Menurut Christi(2016:115) kesalahan konsep tidak saja berujung pada kekeliruan siswa namun hal ini dapat menjadi kesulitan belajar pada materi selanjutnya bagi siswa.

Berdasarkan pelaksanakan proses pembelajaran mengajar dengan cara belajar siswa aktif (CBSA) guru harus lebih aktif mempersiapkan bahan pelajaran, merencanakan proses yang akan dilaksanakan seperti RPP, mempersiapkan evalusai seperti LKS dan tindak lanjut.

Berkenaan dengan hal yang ditersebut guru harus mengembangkan perangkat pembelajran berupa bahan ajar, RPP serta LKS yang dapat digunakan dengan kegiatanseperti mengaikat kehidupan sehari-hari, kerja kelompok hingga sampai berbagi dengan teman. Kondisi ini sangat cocok dengan strategi pembelajaran REACT.

Berdasarkan penelitian yang dilakukan Firda dkk (2016:73) mengatakan bahwa pembelajaran dengan menggunakan srtategi REACT memiliki kelebihan dibandingkan dengan pembelajaran yang biasa yang dilakukan guru.Melalui kegiatan pada strategi REACT siswa dapat menggunakan pengetahuan yang dia miliki sebelumnya dan pengalamnya di kehidupan sehari-hari untuk memahami suatu konsep baru yang diberikan.

Persegi dan persegi panjang merupakan salah satu materi yang dapat diajarkan dengan menggunakan strategi pembelajaran REACT. Pada penerapan kurikulum 2013 materi ini diajarkan pada kelas VII.Sekolah MTsN 1 Maluku Tengah adalah satu sekolah yang menerapkan kurikulum 2013.

Berdasarkan observasi yang dilakukan penulis di sekolah MTsN 1 Maluku Tengah pada tanggal 3 Februari 2018. Tuntutan terhadap siswa seperti yang disampaiakan oleh Muschla dan Gary tidak begitu terlihat pada proses pembelajaran. Penggunaan perangkat pembelajaran seperti bahan ajar dan LKS juga tidak ada.

Dengan demikian rumusan masalah dalam penelitian ini adalah bagaimana mengembangkan Perangkat Pembelajaran Materi Persegi dan Persegi Panjang Dengan Menggunakan Strategi Relating,Experiencing Applying, Cooperating, Transfering (REACT).

\section{Metode Penelitian}

Penelitian ini termasuk dalam penelitian pengembangan. Dalam penelitian ini akan dikembangkan perangkat pembelajaran dengan menggunakan strategi REACT yang meliputi bahan ajar, rencana pelaksanaan pembelajran (RPP), dan lembar kerja siswa pada materi persegi 
dan persegi panjang dikelas VII pada MTsN 1 Maluku Tengah.

Model pengembangan perangkat pembelajaran yang digunakan adalah dengan memodifikasi model 4-D dari Thiagarajan, Semmel dan Semmel (Muchayat:2011). Dalam penelitian ini hanya sampai pada tahap pengembangan (develop). Hal ini dikarenakan adanya barbagai pertimbangan dan batasanmaka pengembangan perangkat pembelajaran hanya dibatasi sampai tahap pengembangan (develop), yaitu sampai padakegiatan uji coba perangkat pembelajaranProses penelitian seperti terlihat pada gambar 1 berikut.

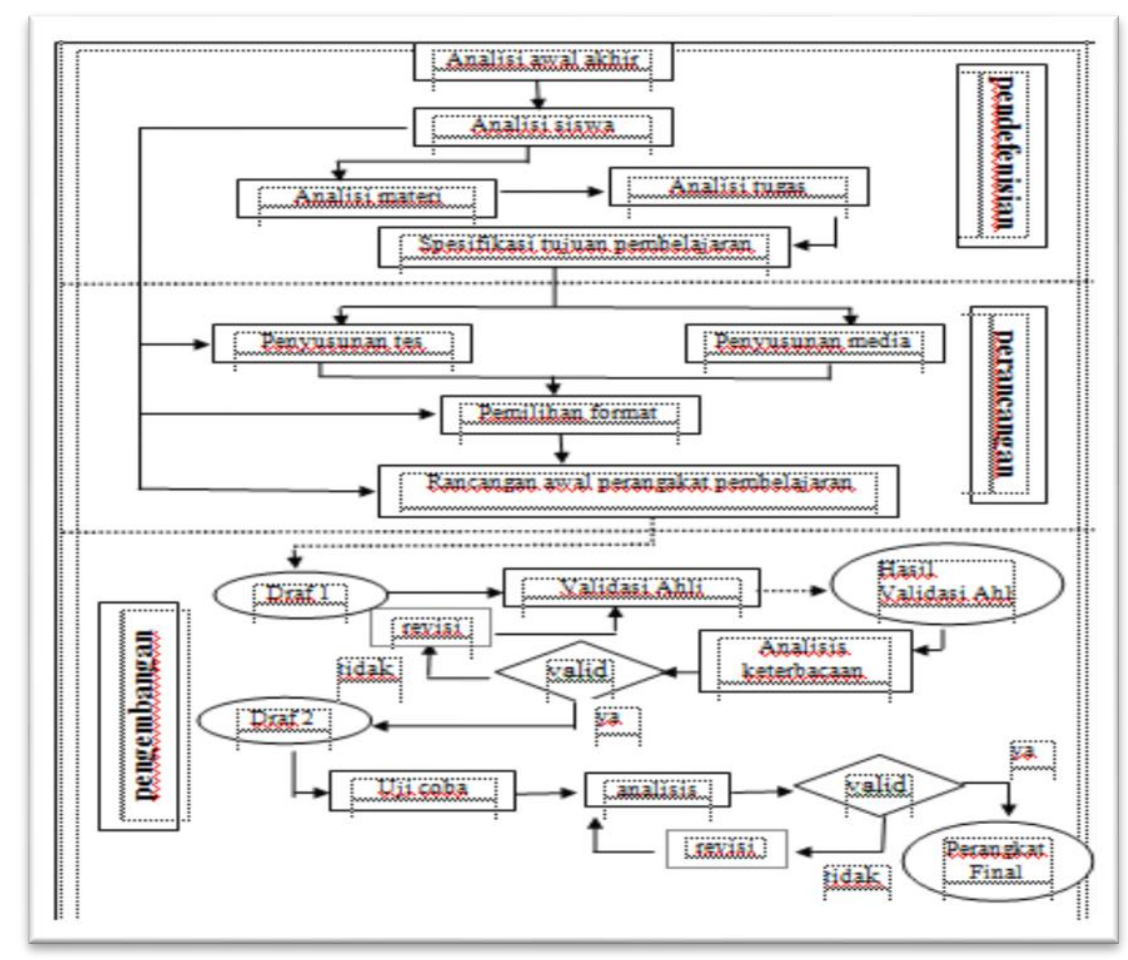

Gambar 1. Diagram alur Pengembangan Perangkat Pembelajaran (Mukhayat, 2011)

Untuk mengumpulkan data dalam penelitian ini dilakukan dengan cara sebagai berikut:

a. Data Hasil Validasi

Data hasil validasi diperoleh berdasarkan hasil validasi oleh validator yang diberikan terhadap instrument penelitian berupa lembar validasi Penilaian terdiri dari 4 kategori, yaitu sangat baik (nilai 4), baik (nilai 3), kurang baik (nilai 2), sangat kurang (nilai 1). Validator juga menuliskan saran dan komentarnya pada lembar validasi.

b. Data Hasil Uji Keterbacaan

Data hasil uji keterbacaan ini dikumpulkan dengan menggunakan lembar uji keterbacaan untuk guru dan siswa. Guru mitra diminta untuk membaca perangkat pembelajaran (RPP,BA, dan LKS), kemudian memberikan komentar berupa masukan atau saran, apabila terdapat hal-hal hal-hal yang kurang jelas atau diperkirakan tidak dapat dilaksanakan dalam pembelajaran. Data Hasil Uji Keterbacaan untuk Siswa dikumpulkan dengan menggunakan lembar uji keterbacaan untuk siswa.Siswa diminta untuk membaca (BA, dan LKS), kemudian memberikan komentar berupa masukan atau saran, apabila terdapat hal-hal hal-hal yang kurang jelas atau rancuh.

c. Data Hasil Uji Coba

Data aktivitas guru mitra dikumpulkan dengan menggunakan lembar pengamatan aktivitas guru.Pengamatan yang dilakukan oleh seorang guru lainnya.Data ini bertujuan untuk mengatahui keterlaksanaan pembelajaran yang dilakukan oleh guru mitra.Data Hasil Pengamatan aktivitas siswa dikumpulkan dengan menggunakan lembar pengamatan aktivitas siswa.Data ini diperoleh melalui pengamatan yang dilakukan pengamat terhadap setiap kelompok siswa.Data respons guru dikumpulkan dengan menggunakan angket respons guru terhadap perangkat pembelajaran, yang diberikan kepada guru mitra sekolah setelah melakukan kegiatan 
pembelajaran.Data respons siswa dikumpulkan dengan menggunakn angket respons siswa terhadap perangkat pembelajaran yang diberikan kepada siswa setalah pembelajaran.

d. Data Hasil Pembelajaran Siswa

Data hasil belajar siswa dikumpulkan dengan memberikan tes terhadap siswa setelah kegiatan pembelajaran.

\section{Hasil dan Pembahasan}

\subsection{Hasil}

Penelitian ini dilakukan untuk siswa kelas VII MTsN 1 Maluku Tengah tahun pelajaran 2017/2018 yang dilakukan selama empat kali tatap muka. Penelitian ini dimulai dengan tahap pendefenisian, dilanjutkan tahap perancangan. Tahap ini dilakukan validasi terhadap perangkat pembelajaran yang disusun hingga menjadi rancangan awal dan diperoleh data sebagai berikut.

Tabel 1. Hasil Penilaian Umum Validator terhadap Perangkat Pembelajaran

\begin{tabular}{|c|c|c|c|c|c|}
\hline \multirow{2}{*}{ No } & \multirow{2}{*}{$\begin{array}{c}\text { Perangkat yang } \\
\text { divalidasi }\end{array}$} & \multicolumn{3}{|c|}{ Validator } & \multirow{2}{*}{$\mathbf{Z}$} \\
\hline & & 1 & 2 & 3 & \\
\hline 1 & RPP & 4 & 3 & 4 & 3.7 \\
\hline 2 & BA & 4 & 2 & 4 & 3.3 \\
\hline 3 & LKS & 4 & 3 & 4 & 3.7 \\
\hline \multicolumn{5}{|c|}{ Rs } & 3.6 \\
\hline
\end{tabular}

Berdasarkan hasil penilaian umum validator seperti terlihat pada tabel 1 diperoleh rerata skor (Rs) yang diberikan oleh validator adalah 3,6. Kesimpulannya perangkat pembelajaran dengan menggunakan strategi REACT dianggap memenuhi kriteria sangat baik, sehingga dapat digunakan dengan sedikit revisi berdasarkan saran dari para validator.
Selanjutnya untuk uji keterbacaan, dilakukan sedikit revisi berdarkan komentar dan kritik dari guru dan siswa.Tahap selajutnya melakukan uji coba perangkat yang meliputi data hasil observasi uji keterlaksanaan siswa dan guru dan angket respon guru dan siswa seperti yang terlihat pada tabel berikut ini.

Tabel 2. Hasil Analisis Pengamatan Aktivitas Guru pada Pelaksanaan Uji Coba Perangkat Prembelajaran

\begin{tabular}{|c|c|c|c|c|c|c|c|c|c|}
\hline \multirow{3}{*}{ No } & \multirow{3}{*}{ Aktivitas } & \multicolumn{8}{|c|}{ Keterlaksanaan } \\
\hline & & \multicolumn{2}{|c|}{ Pertemuan 1} & \multicolumn{2}{|c|}{ Pertemuan 2} & \multicolumn{2}{|c|}{ Pertemuan 3} & \multicolumn{2}{|c|}{ Pertemuan 4} \\
\hline & & Ya & Tidak & Ya & Tidak & Ya & Tidak & Ya & Tidak \\
\hline \multirow[t]{5}{*}{1.} & Pendahuluan : & & & & & & & & \\
\hline & $\begin{array}{l}\text { 1. Membuka atau memulai } \\
\text { pembelaiaran dengan salam }\end{array}$ & 1 & 0 & 1 & 0 & 1 & 0 & 1 & 0 \\
\hline & $\begin{array}{l}\text { 2. Meminta salah satu } \\
\text { siswanya memimpin doa }\end{array}$ & 1 & 0 & 1 & 0 & 1 & 0 & 1 & 0 \\
\hline & $\begin{array}{l}\text { 3. Memeriksa kehadiran } \\
\text { sebagai sikap disiplin }\end{array}$ & 0 & 1 & 1 & 0 & 1 & 0 & 1 & 0 \\
\hline & $\begin{array}{l}\text { 4. Menyampaikan tujuan } \\
\text { pembelajaran yang ingin } \\
\text { dicapai }\end{array}$ & 0 & 1 & 0 & 1 & 0 & 1 & 1 & 0 \\
\hline \multirow[t]{5}{*}{2.} & & & & & & & & & \\
\hline & $\begin{array}{l}\text { 1. Relating: } \\
\text { Bertanya kepada siswa }\end{array}$ & 1 & 0 & 1 & 0 & 1 & 1 & 1 & 0 \\
\hline & $\begin{array}{l}\text { tentang benda-benda di } \\
\text { sekitar yang berkaitan } \\
\text { dengan materi. }\end{array}$ & & & & & & & & \\
\hline & $\begin{array}{l}\text { 2. Experiencing: } \\
\text { Meminta siswa untuk } \\
\text { menuliskan atau melakukan } \\
\text { kegiatan yang akan menuju } \\
\text { ke inti materi. }\end{array}$ & 1 & 0 & 1 & 0 & 1 & 0 & 1 & 0 \\
\hline & $\begin{array}{l}\text { 3. Applying } \\
\text { Meminta siswa untuk }\end{array}$ & 1 & 0 & 1 & 0 & 1 & 0 & 1 & 0 \\
\hline
\end{tabular}




\begin{tabular}{|c|c|c|c|c|c|c|c|c|c|}
\hline & $\begin{array}{l}\text { menerapkan informasi yang } \\
\text { didapat kedalam materi } \\
\text { maupun menyelesaiakan } \\
\text { soal } \\
\text { 4. Cooperating: } \\
\text { Meminta siswa bekerja } \\
\text { dalam kelompok } \\
\text { 5. Transfering: } \\
\text { Meminta siswa untuk } \\
\text { mempresentasikan hasil } \\
\text { diskusi kelompok, dan } \\
\text { saling bertukar pikiran } \\
\text { dengan kelompok lain }\end{array}$ & 1 & 0 & 1 & 0 & 1 & 0 & 1 & 0 \\
\hline 3 & $\begin{array}{l}\text { Penutup: } \\
\text { 1. Guru bersama siswa } \\
\text { menarik kesimpulan tentang } \\
\text { pembelajaran yang telah } \\
\text { dilaksanakan } \\
\text { 2. Menyampaikan materi } \\
\text { berikutnya untuk pertemuan } \\
\text { berikutnya } \\
\text { 3. Meminta salah satu siwa } \\
\text { memimpin doa } \\
\text { 4. Mengucapkan salam }\end{array}$ & $\begin{array}{l}1 \\
1 \\
\end{array}$ & $\begin{array}{l}0 \\
0 \\
\end{array}$ & $\begin{array}{l}1 \\
1 \\
\end{array}$ & $\begin{array}{l}0 \\
0 \\
\end{array}$ & $\begin{array}{l}1 \\
1 \\
\end{array}$ & $\begin{array}{l}0 \\
0 \\
\end{array}$ & $\begin{array}{l}1 \\
1 \\
\end{array}$ & $\begin{array}{l}0 \\
0 \\
\end{array}$ \\
\hline \multicolumn{2}{|r|}{$\operatorname{Ag}(\%)$} & $\begin{array}{l}77 \\
\%\end{array}$ & $31 \%$ & $\begin{array}{l}85 \\
\%\end{array}$ & $15 \%$ & $\begin{array}{l}92 \\
\%\end{array}$ & $8 \%$ & $\begin{array}{c}100 \\
\%\end{array}$ & $0 \%$ \\
\hline
\end{tabular}

Berdasarkan tabel 2 menunjukkan terlaksana kegiatan guru mencapa lebih dari $70 \%$ dan mengalami kenaikkan. Pertemuan pertama $77 \%$, kedua $85 \%$, ketiga $92 \%$ dan pertemuan keempat $100 \%$ terlaksana, sehingga dapat disimpulkan aktivitas guru dapat terlaksana/efektif.

Aktivitas siswa di amati oleh 6 orang observer. Masing-masing observer mengamati satu kelompok.hasil analisisnya terlihat pada tabel 3 berikut ini.

Tabel 3. Hasil Analisis Kegiatan Siswa dalam Kelompok

\begin{tabular}{|c|c|c|c|c|c|c|c|c|c|c|c|c|c|}
\hline \multirow{3}{*}{ Pertemuan ke } & \multicolumn{12}{|c|}{ Keterlaksanaan (\%) } & \multirow{3}{*}{ As } \\
\hline & \multicolumn{2}{|c|}{ Kel 1} & \multicolumn{2}{|c|}{ Kel 2} & \multicolumn{2}{|c|}{ Kel 3} & \multicolumn{2}{|c|}{ Kel 4} & \multicolumn{2}{|c|}{ Kel 5} & \multicolumn{2}{|c|}{ Kel 6} & \\
\hline & ya & Tdk & ya & $\mathrm{tdk}$ & ya & tdk & ya & tdk & ya & $\mathrm{tdk}$ & ya & tdk & \\
\hline $\mathrm{I}$ & 87 & 13 & 84 & 16 & 91 & 9 & 93 & 7 & 84 & 16 & 87 & 13 & 88 \\
\hline II & 91 & 9 & 87 & 13 & 89 & 11 & 96 & 4 & 87 & 13 & 89 & 11 & 90 \\
\hline III & 91 & 9 & 89 & 11 & 91 & 9 & 96 & 4 & 91 & 9 & 91 & 9 & 92 \\
\hline \multirow[t]{2}{*}{ IV } & 93 & 7 & 91 & 9 & 96 & 4 & 100 & 0 & 96 & 4 & 93 & 7 & 95 \\
\hline & \multicolumn{12}{|c|}{ Rata-rata Keseluruhan(\%) } & 91,25 \\
\hline
\end{tabular}

Berdasarkan data table 3, menunjukkan bahwa keterlaksanaan aktivitas siswa mencapai angka $>70 \%$.Rata-rata keseluruhan juga mencapai angka $>70 \%$.Sehinnga dapat disimpulkan bahwa aktivitas siswa terlaksana secara efektif.Hasil dari angket respon yang diberikan kepada guru terhadap perangkat pembelajaran menggunakan strategi REACT terlihat pada tabel 4 berikut ini.

Tabel 4. Hasil Analisi Angket Respon Guru Terhadap Perangkat Pembelajaran

\begin{tabular}{|c|c|c|c|c|c|}
\hline \multirow{2}{*}{ Perangkat Pembelajaran } & \multicolumn{5}{|c|}{ Respons Guru } \\
\hline & SS & $\mathbf{S}$ & $\mathbf{R R}$ & TS & STS \\
\hline $\begin{array}{l}\text { 1. Bahan Ajar(BA) } \\
\text { a. Tampilan cover dan isi BA menarik dan mudah } \\
\text { dipahami.. }\end{array}$ & 1 & 0 & 0 & 0 & 0 \\
\hline
\end{tabular}




\begin{tabular}{|l|l|l|l|l|l|l|}
\hline b. Bahan ajar yang dibuat sesuai dengan indikator & 1 & 0 & 0 & 0 & 0 \\
c. BA membantu siswa menemukan konsep materi. & 1 & 0 & 0 & 0 & 0 \\
d. Bahan ajar membuat siswa belajar mandiri. \\
e. Bahan ajar menumbuhkan rasa ingin tahu siswa \\
f. Isi dari bahan ajar mencerminkan strategi \\
REACT.
\end{tabular}

Berdasarkan tabel 4 terlihat bahwa tabel bahwa respon SS mencapai nilai $58,3 \%$ dan S mencapai 33,3 serta RR mendapat 8,3\% sedangkan TS dan STS.

Sama-sama 0\% . Respon positif yang diperoleh merupakan respon yang bernilai $\mathrm{S}$ dan SS oleh karena itu, respon positif yang diberikan guru adalah 100\% sehinngga dapat disimpulkan bahwa perangkat pembelajaran dikatakan baik/ efektif, dikarenakan respon positif yang diperoleh $>70 \%$. Hasil analisi respon siswa diperoleh dari angket yang di isi oleh 30 orang siswa seperti pada terlihat pada tabel 5 berikut ini.

Tabel 5. Hasil Analisi Angket Respon Siswa Terhadap Perangkat Pembelajaran

\begin{tabular}{|l|c|c|c|c|c|}
\hline \multicolumn{2}{|c|}{ Perangkat Pembelajaran } & \multicolumn{3}{|c|}{ Respons Siswa } \\
\cline { 2 - 6 } & SS & S & RR & TS & STS \\
\hline 1. Bahan Ajar (BA) & & & & & \\
a. Tampilan cover dan design isi BA menarik serta & 83 & 17 & 0 & 0 & 0 \\
$\quad$ mudah dipahami & & & & & \\
b. BA membantu siswa menemukan konsep materi. & 57 & 43 & 0 & 0 & 0 \\
c. Bahan ajar membuat siswa belajar mandiri. & 87 & 13 & 0 & 0 & 0 \\
\hline Lembar Kerja Siswa (LKS) & & & & & \\
a. LKS mudah dipahami siswa. & 80 & 20 & 0 & 0 & 0 \\
b. LKS memfasilitasi siswa untuk memahami materi. & 70 & 20 & 10 & 0 & 0 \\
c. LKS mempermudahkan siswa untuk belajar. & 73 & 23 & 0 & 0 & 0 \\
\hline Pelaksanaan Pembelajaran & & & & & \\
a. Strategi REACT membuat pembelajaran lebih aktif & 43 & 57 & 0 & 0 & 0 \\
b. Suasana pembelajaran di kelas tampak baru dan & 67 & 33 & 0 & 0 & 0 \\
menyenangkan. & & & & & \\
c. Siswa bersemangat dalam proses pembelajaran. & 73 & 27 & 0 & 0 & 0 \\
d. Karena Strategi REACT berpusat kepada siswa & 60 & 40 & 0 & 0 & 0 \\
$\quad$ sehingga guru tidak mendominasi proses & & & & & \\
\hline pembelajaran & & & & & $\mathbf{2}$ \\
\hline
\end{tabular}

Berdasarkan tabel 5 menunjukkan, respon positif siswa meliputi respon setuju (S) dan sangat setuju (SS) mencapai 98\%, dengan respon RR 2\% TS dan STS masing-masing 0\%. Respon positif siswa melebihi angka $\mathbf{7 0 \%}$ sehingga dapat disimpulkan bahwa respon positif siswa sangat baik terhadap perangkat pembelajaran.

Tes hasil belajar dilakukan untuk mengetahui tingkat pemahaman, penguasaan serta kesuksesan seorang guru bahkan ketepatan perangkat pembelajaran yang digunakan terhadap materi yang telah dipelajari. Hasil dari tes belajar siswa yang diikuti oleh 30 siswa, 21 orang siswa mampu mencapai KKM dan melewatinya sedangkan 9 orang siswa sisanya mendapatkan nilai di bawah KKM. Sehingga diperoleh persentase rata-rata siswa yang mencapai KKM sebesar $70 \%$. Oleh karena itu, dapat disimpulkan bahwa perangkat pembelajaran serta strategi pembelajaran yang digunakan dapat dikatakan baik dikarenakan 
persentase siswa yang mencapai KKM sudah melebihi kriteria yang minimum yaitu $>65 \%$ siswa yang harus mencapai KKM.

\section{Kesimpulan}

Berdasarkan hasil penelitian yang telah dilakukan terhadap pengembangan perangkat pembelajaran RRP, BA, dan LKS dengan menggunakan strategi REACT untuk siswa kelas VII MTsN 1 Maluku Tengah materi persegi dan persegi panjang dapat disimpulkan bahwa perangkat pembelajaran telah memenuhi criteria valid, setelah melalui berbagai tahapan sesuai dengan model pengembangan perangkat pembelajaran 4-D yang telah dimodifikasi yaitu tahap pendefenisian (define), perancangan (design) dan tahap pengembangan (develop) yang diikuti berbagai kegiatan-kegiatan.

Penelitian yang dimulai dengan kegiatan validasi oleh para ahli dan revisi yang memenuhi penilaian umum mencapai 3.6.diperlakukan uji keterbacaan seta diuji cobakan dengan keterlaksanaan mencapai $100 \%$ pada pertemuan keempat berdasarkan pada aktivitas guru. Selain itu juga pada keterlaksanaan aktivitas siswa secara keseluruhan yang mencapai 91,25\%. Respon baik guru yang meliputi respon sangat setuju(SS) dan setuju (S) mencapai 100\% dan respon positif siswa yang meliputi respon sangat setuju(SS) dan setuju(S) mencapai 98\%. Berdasarkan tes hasil belajar siswa yang dilakukan oleh 30 orang siswa mencapai angka ketuntasan hingga $70 \%$.

Berdasarkan uraian diatas terlihat bahwa semua kriteria perangkat pembelajaran baik/valid sudah terpenuhi sehingga terbukti bahwa perangkat pembelajaran yang telah dikembangkan berupa RPP , Bahan ajar dan LKS dikatakan baik/valid.

Berdasarkan tahapan dari hasil penelitian yang telah dilakukan ada beberapa hal yang yang perlu diperhatikan dan dapat menjadi pertimbangan dalam pembelajara. Untuk itu peneliti menyarankan bebrapa hal sebagai beikut:

a. Perangkat pembelajaran ini sudah dikatakan valid. Sehingga disarankan bagi guru untuk dapat menguji cobakan perangkat pembelajaran ini untuk kelas lainnya. Dan diharapkan dapat memperoleh perangkat pembelajaran yang lebih berkualitas sebagai kelanjutan tahapan model pengembangan 4-D yaitu tahap penyebaran.

b. Dalam proses pembelajaran berikutnya diharapkan guru dapat menggunakan strategi pembelajaran REACT dan mengembangkan perangkat pembelajaran berupa RPP. BA dan LKS lainnya.

Bagi para peneliti yang berniat untuk melakukan penelitian pengembangan perangkat menggunakan strategi REACT untuk dapat memerhatikan segala keterbatasan dan kelemahan dalam penelitian agar dapat menghasilkan perangkat pembelajaran yang lebih baik lagi.

\section{Daftar Pustaka}

Ahmadi,K.Iif\& Sofan Amri,2014.Pengembangan \& Model Pembelajaran Tematik Integratif. Jakarta :Prestasi Pustaka

Crawford, L. Michael. 2011. Teaching Contextually, Research, Rationale, And Techniques for Improving Students Motivation and Achievement in Mathematics and science.Cord.Oktober 2001. (diakses pada 22 januari 2018).

Firda dkk.2016.Penerapan Strategi REACT (Relating, Experiencing, Applying, Cooperating, Transfering) untuk Meningkatkan Kemampuan Koneksi Matematika Siswa pada Pokok Bahasan Bangun Datar dikelas VII-2 SMP Negeri 47 Jakarta. (diakses 11 februari 2018).http://jurnal.unj.ac.id/unj/index.php/jrpms /article/download/3029/2190

Joyce bruce, dkk . 2009. Models of Teaching ModelModel Pembelajaran.Yogyakarta : Pustaka Pelajar

Muschla,A. Judith dan Gary Robert Muschla.2009.Pedoman Praktis Tugas-Tugas Matematika dengan Aplikasi Kehidupan Nyata Sehari-Hari.Jakarta : PT Indeks

Laurens T, Laamena C dan Mattitaputty C. 2014. Delopment A Set of Instructional Learning Based Realistic Mathematics Education and Local Wisdon. Prosiding $1^{\text {st }}$ ISIM-MED 2014. EP 571-576. Nopember 26-30 2014.

Thobroni Muhammad \& Arif Mustafa.2012. Belajar dan pembelajaran Pengembangan wacana dan Praktik Pembelajaran dalam pembagunan nasional. Jogjakarta: Ar-Ruzz Media

Uno,B. Hamzah. 2007. Model Pembelajaran Menciptakan Proses Belajar Mengajar yang Kreatif dan Efektif.Jakarta : PT Bumi Aksara 